\title{
HUBUNGAN ANTARA KUALITAS KEHIDUPAN KERJA DAN KETERIKATAN KERJAPADA PEKERJA WANITA
}

\author{
Annisaa Miranty Nurendra ${ }^{1}$ Wilda Purnamasari ${ }^{2}$ \\ ${ }^{1,2}$ Program Studi Psikologi, Fakultas Psikologi dan IImu Sosial Budaya \\ Islamic University of Indonesia \\ 12annisaa.miranty@uii.ac.id
}

\begin{abstract}
This study aims to determine the relationship between quality of work life and work engagement. The research hypothesis is taken on the assumption that high quality of life correlates with high work attachment. Subjects in this study were 100 women workers taken based on the sampling quotas. The age of the study subjects was in the range of 20-55 years, unmarried and married. The research data was taken using two translated scales, ie Urtrecth Work Engagement Scale (UWES) 17 was developed by Schaufeli, Bakker and Salanova (2006) to measure work attachment and, and work life quality scale developed by Swamy, Nandunjeswaraswamy and Rashmi (2015). The collected data were analyzed using spearmanrho correlation technique. The result showed that there was a positive correlation between quality of work life and work attachment with $r=0.695$ and $p=0.000(p<0.05)$. Effective contribution to worker attachment to female workers is $48.3 \%$. From uUji independent sample t test can be concluded that, there is no difference of work attachment between married and unmarried workers, and there is no difference of work attachment in terms of number of children.
\end{abstract}

Key words : work engagement, quality of work life, women career

Abstrak. Penelitian ini bertujuan untuk mengetahui hubungan antara kualitas kehidupan kerja dan keterikatan kerja. Hipotesis penelitian diambil berdasar asumsi bahwa kualitas pekerjaan yang tinggi berkorelasi dengan keterikaatan kerja yang tinggi. Subjek dalam penelitian ini adalah pekerja wanita sejumlah 100 orang yang diambil berdasarkan kuota sampling. Usia subjek penelitian berada pada rentang 20 - 55 tahun, belum menikah dan sudah menikah. Data penelitian diambil menggunakan dua skala yang telah diterjemahan, yaitu Urtrecth Work Engagement Scale (UWES)17 dikembangkan oleh Schaufeli, Bakker dan Salanova (2006) untuk mengukur keterikatan kerja dan, dan skala kualitas kehidupan kerja dikembangkan oleh Swamy, Nandunjeswaraswamy dan Rashmi (2015). Data yang terkumpul dianalisis dengan menggunakan teknik korelasi spearmanrho Hasil menunjukkan bahwa terdapat hubungan positif antara kualitas kehidupan kerja dan keterikatan kerja. Sumbangan efektif terhadap keterikatan kerja pada pekerja wanita sebesar $48.3 \%$. Dari uUji independent sample $t$ test dapat disimpulkan bahwa, tidak ada perbedaan keterikatan kerja antara pekerja yang menikah dan belum menikah, dan tidak ada perbedaan keterikatan kerja ditinjau dari jumlah anak.

Kata Kunci : Keterikatan kerja, Kualitas kehidupan kerja, Pekerja wanita

\section{PENDAHULUAN}

Di era globalisasi sekarang ini, karyawan yang bekerja di perusahaan bukan hanya kaum laki-laki saja, akan tetapi wanita juga ikut andil dalam menjalankan suatu organisasi atau perusahaan. Wanita yang bekerja di sebuah orgaisasi atau perusahaan disebut waita karir. Stevenson (2010) mengartikan bahwa pekerja wanita adalah wanita yang bekerja serta mendapatkan upah. Pekerja wanita adalah mereka yang hasil karyanya mendapatkan imbalan berupa uang (Ilhromi, 2000). Pekerja wanita berarti memiliki dua pekerjaan yaitu peran domestik dan pekerjaan kantor. Ketika 
memiliki pekerjaan berlebih maka jam kerjanya tentu melebihi 6-8 jam. Ini dapat menurunkan efisiensi kerja, kelelahan, dan menimbulkan penyakit (Matlin dalam Nilakusmawati \& Susilawati, 2012)

Dari hasil wawancara yang telah dilakukan ditemukan bahwa subjek merasa bahwa pekerjaan yang dilakukannya adalah pekerjaan yang kurang menyenangkan ini menandakan bahwa subjek tidak memenuhi pada salah satu aspek keterikatan kerja yaitu pada aspek dedikasi (dedication), yaitu mengarah pada keterikatan yang sangat tinggi saat mengerjakan tugas dan mengalami perasaan yang berarti, sangat antusias, penuh inspirasi, kebanggaan, dan menyukai tantangan (chalenge at work), namun yang dirasakan subjek justru kebalikannya. Subjek juga merasa tertekan dengan tuntutan pekerjaannya, merasa jenuh dan bosan terhadap pekerjaan semangat ini menandakan subjek tidak memenuhi pada salah satu aspek dari keterikatan kerja yaitu semangat (vigor). Semangat (vigor) merupakan tingkat energi yang tinggi, daya tahan secara fisik dan mental, kesediaan untuk berusaha, ketekunan (ketabahan) atau mental yang kuat dalam menghadapi kesulitan ketika bekerja, keberanian untuk berusaha sekuat tenaga dalam menyelesaikan suatu pekerjaan, namun yang dirasakan subjek justru kebalikannya. Adanya beberapa keluhan yang dialami tersebut membuat subjek terkadang berfikir untuk berhenti dari pekerjaannya (resign) sehingga mengakibatkan ketidakmampuan dalam menyelesaikan tugas-tugasnya di kantor.

Pernyataan ini didukung oleh penelitian yang dilakukan Lee (Rahayuningsih, 2013) menunjukkan bahwa jumlah turnover pada wanita lebih banyak yaitu $65,3 \%$ sedangkan laki-laki sebanyak $34,6 \%$. Ini dikarenakan wanita cepat menderita kelelahan, kecemasan, gangguan psikologis sedang, dan gejala somatik (Jick \& Miltz, 1985).

Karyawan yang memiliki keterikatan kerja yang tinggi akan menunjukkan performa terbaik mereka, hal ini dikarenakan karyawan menikmati segala aktifitas yang dilakukannya (Bakker \&
Leiter, 2010). Sebaliknya, apabila keterikatan kerja rendah, karyawan akan merasakan adanya tekanan dalam pekerjaan. Adanya tekanan dalam pekerjan tentu akan berdampak pada hasil pengerjaan tugas atau pekerjaan tersebut, karena karyawan merasakan tugas atau pekerjaannya dirasa sebagai beban kerja yang harus diselesaikan.

Keterikatan sendiri dipengaruhi oleh tiga faktor dimana dua faktor dikemukakan oleh Bakker (2011) yaitu sumber kerja (job resources) dan sumber daya pribadi (personal resources). Sumber pekerjaan merupakan salah satu faktor ekstrinsik yang didapatkan karyawan ketika berada di tempat kerja. Tidak terkecuali kualitas kehidupan kerja, ini merupakan bagian yang tidak dapat dipisahkan dari sumber pekerjaan, karena kualitas kehidupan kerja merupakan sebuah usaha dalam pemenuhan kebutuhan karyawan untuk menjalankan tugasnya dengan baik dan efisien ketika di tempat kerja. Tidak hanya itu, kualitas kehidupan kerja juga mampu membuat karyawan merasa nyaman dengan pekerjaannya (Sinha, 2012). Ketika karyawan merasa nyaman, maka karyawan dapat memberikan efek positif dalam pemenuhan tugasnya. Hal ini menunjukkan bahwa kualitas kehidupan kerja memberikan keseimbangan baik dalam pribadi dan kehidupan profesional seorang individu (Islam, 2012). Hal ini juga ditemukan oleh Katen dan Sadullah (2012) yang melakukan penelitian empiris pada kualitas kehidupan kerja dan keterikatan kerja memiliki hubungan positif.

Menurut Robbins (Gayathiri \& Ramakrishnan, 2013) kualitas kehidupan kerja merupakan suatu proses organisasi yang sadar dan merespon kebutuhan karyawan dengan mengembangkan mekanisme untuk memungkinkan karyawan untuk bertukar pikir sepenuhnya dalam membuat keputusan yang berguna untuk merancang kehidupan kerja mereka. Hal ini merujuk pada pemikiran bahwa kualitas kehidupan kerja dipandang mampu untuk meningkatkan peran serta, produktivitas baik dari karyawan terhadap organisasi atau perusahaan. Subhashini dan Gopal (2013) menuturkan bahwa organisasi diharuskan untuk mengadopsi 
strategi untuk meningkatkan kualitas kehidupan kerja karyawan untuk memenuhi dua tujuan yaitu tujuan organisasi dan kebutuhan karyawan.

Kanten dan Sadullah (2012) meneliti tentang penelitian empiris pada kualitas kehidupan kerja dan keterikatan kerja di perusahaan marmer teresar di Turki. Penelitian ini dilakukan menggunakan kuisioner dengan responden sebanyak 156 karyawan yang terdiri dari laki-laki dan perempuan. Tujuan dari penelitian ini adalah untuk menyelidiki dan menentukan hubungan antara kualitas kehidupan kerja dan keterikatan kerja di sebuah perusahaan marmer terbesar di Turki. Hasil dari penelitian ini adalah terdapat hubungan positif antara kualitas kehidupan kerja dan keterikatan kerja.

Normala dan Daud (2010) meneliti tentang hubungan antara program kualitas kehidupan kerja dan kualitas hidup antar karyawan di perusahaan multinasional di Bintulu, Sarawak, Malaysia. Para peserta terdiri dari 179 karyawan saat ini bekerja di perusahaan multinasional di Bintulu, Sarawak. Responden dipilih secara acak dan data dikumpulkan melalui penyebaran kuisioner. Studi ini menemukan bahwa ada hubungan yang signifikan antara kualitas program kualitas kehidupan kerja dan kualitas hidup. Hasil penelitian juga menunjukkan bahwa ada hubungan yang positif dan signifikan antara program kualitas kehidupan kerja dan kualitas hidup.

Berdasarkan hal tersebut peneliti tertarik untuk meneliti adakah hubungan antara kualitas kehidupan kerja dan keterikatan kerja pada pekerja wanita, dengan hipotesis ada hubungan positif antara kualitas kehidupan kerja dan keterikatan kerja pada pekerja wanita. Selain untuk mengetahui (1) hubungan antara kualitas kehidupan kerja dan keterikatan kerja pada pekerja wanita, penelitian ini juga bertujuan untuk (2) mengetahui berapa sumbangan efektif tiap aspek dari kualitas kehidupan kerja dan ketertarikan kerja pada pekerja wanita, dan (3) perbedaan jawaban antara subjek yang belum menikah, sudah menikah tetapi belum memiliki anak dan subjek yang sudah menikah dan sudah memiliki anak terkait keterikatan kerja.

\section{METODE PENELITIAN}

Subjek dalam penelitian ini adalah pekerja wanita sejumlah 100 orang yang diambil berdasarkan kuota sampling. Usia subjek penelitian berada pada rentang 20 - 55 tahun, belum menikah dan sudah menikah. Peneliti menggunakan skala Utrecht Work Engagement Scale-17 (UWES-17) yang dikembangkan oleh Schaufeli, Salanova dan Bakker (2006) untuk mengukur keterikatan kerja pekerja wanita dengan total 17 item. Peneliti menggunakan skala kualitas kehidupan kerja yang dikembangkan oleh Swamy, Nandunjeswaraswamy dan Rashmi (2015) untuk mengukur kualitas kehidupan kerja dengan total 50 item. Data dianalisis dengan menggunakan beberapa teknik: (1) Korelasi Spearman Rho, untuk mengetahui tujuan pertama penelitian yaitu hubungan antara kualitas kehidupan kerja dan keterikatan kerja pada pekerja wanita uji ini digunakan karena data yang diperoleh tidak memenuhi uji asumsi untuk analisis product moment Pearson, (2) Nilai $r^{2}$ untuk mengetahui sumbangan efektif variabel, dan (3) Uji T-tes untuk mengetahui perbedaan jawaban antara subjek yang belum menikah, sudah menikah tetapi belum memiliki anak dan subjek yang sudah menikah dan sudah memiliki anak terkait keterikatan kerja.

\section{HASIL DAN PEMBAHASAN}

Hubungan antara Kualitas kehidupan kerja dan Keterikatan Kerja berdasarkan hasil analisis menunjukkan bahwa koefisien korelasi $r=0,695$ dengan $p=$ $0,000 \quad(p<0,01)$. Berdasarkan hasil tersebut, dapat dilihat bahwa terdapat hubungan positif yang sangat signifikan antara kualitas kehidupan kerja dengan keterikatan kerja. Hal ini dapat diartikan bahwa semakin tinggi kualitas kehidupan kerja, maka semakin tinggi pula tingkat keterikatan kerja begitu sebaliknya, apabila kualitas kehidupan rendah maka keterikatan kerja juga rendah. Berdasarkan penjelasan tersebut, maka hipotesis penelitian dapat diterima. 
Tabel 1

Hasil Uji Hipotesis Kualitas kehidupan kerja dan Keterikatan Kerja

\begin{tabular}{ccccc}
\hline Variabel & $\mathbf{r}$ & $\mathbf{r}^{2}$ & $\mathbf{P}$ & Keterangan \\
\hline $\begin{array}{c}\text { Kualitas kehidupan kerja } \\
\text { dan Keterikatan kerja }\end{array}$ & 0.695 & 0.483 & 0.000 & $\begin{array}{c}\text { Terdapat } \\
\text { hubungan positif }\end{array}$ \\
\hline
\end{tabular}

Matlin (Nilakusmawati \& Susilawati, 2012) menggunakan istilah ibu bekerja yang mengacu kepada dua peran, yaitu wanita yang bekerja di luar rumah untuk memperoleh penghasilan sebagai imbalan kerjanya dan wanita yang tidak memperoleh penghasilan karena bekerja di dalam rumah. Ini artinya pekerja wanita memiliki dua peran yaitu peran sebagai ibu rumah tangga dan peran sebagai karyawan. Ibu bekerja tidak hanya mengurus urusan keluarga namun juga mengembangkan dan berinvestasi dalam karirnya (Grady dan McCarthy, 2008). Tingginya tuntutan dari pekerjaan dan keluarga, tentu akan menguras energi, mental yang akhirnya memunculkan ketidaknyamanan secara psikologis. Schaufeli, Bakker, \& Rhenen (2009) menyebutkan seiring tingginya tuntutan pekerjaan maka karyawan akan mengerahkan berbagai upaya untuk memenuhi tuntutan peran tersebut dengan tetap menjaga tingkat kinerjanya

Kualitas kehidupan kerja merupakan masalah utama yang patut untuk mendapatkan perhatian dari sebuah organisasi. Hal ini merujuk pada pemikiran bahwa kualitas kehidupan kerja dipandang mampu untuk meningkatkan peran serta, produktivitas baik dari karyawan terhadap organisasi atau perusahaan (Lewis dkk, 2001).

Keterikatan kerja merupakan salah satu aspek yang dipengaruhi oleh kualitas kehidupan kerja sesuai dengan hasil penelitian yang menunjukkan bahwa $R$ square bernilai 0.483 berarti bahwa kualitas kehidupan kerja memberikan sumbangan efektif terhadap keterikatan kerja pada pekerja wanita sebesar $48.3 \%$. Hal ini membuktikan bahwa kualitas kehidupan kerja berpengaruh terhadap keterikatan kerja pada pekerja wanita sebesar $48.3 \%$, sedangkan $51.7 \%$ sisanya menunjukkan besarnya pengaruh variabel- variabel lain yang juga mempengaruhi keterikatan kerja pada pekerja wanita. Hal ini didukung oleh penelitian yang dilakukan IImiah (2015) bahwa kualitas kehidupan kerja menjadi prediktor untuk memprediksi keterikatan kerja karyawan. Ini menunjukkan bahwa kualitas kehidupan kerja pada pekerja wanita perlu diperhatikan, karena dapat mempengaruhi keterikatan kerja. Seperti yang telah dijelaskan bahwa wanita merupakan tenaga kerja yang potensial dibuktikan dengan $36 \%$ posisi senior di dalam perusahaan dipegang oleh wanita khususnya di Indonesia (CNN Indonesia, 2016). Tetapi, wanita memiliki beberapa kelemahan yaitu cepat menderita kelelahan, kecemasan, gangguan psikologis sedang, dan gejala somatik (Jick \& Miltz, 1985) tidak hanya itu, data turnover pada wanita juga lebih tinggi dari laki-laki menurut hasil penelitian Lee (Rahayuningsih, 2013). Ketika pekerja wanita mengalami hal tersebut, tentu akan berpengaruh terhadap kualitas, produktifitas, serta akan berakibat buruk pada pencapaian organisasi atau perusahaan.

Maka dari itu, untuk menjaga kualitas dan produktifitas, meminimalisir turnover hal yang harus dilakukan organisasi atau perusahaan adalah memerikan kualitas kehidupan kerja yanng baik. Mengacu pada teori yang dikemukakan oleh Yadav dan Khanna (2014) menyatakan bahwa sebuah kualitas kehidupan kerja adalah penting bagi organisasi untuk terus menarik dan mempertahankan karyawan dan memberikan segala hal yang diperlukan bagi sumber daya manusia adalah langkah yang bagus untuk mendorong sumber daya manusia tersebut untuk melakukan pekerjaan secara produktif serta berkualitas bagi organisasi. Pemenuhan kebutuhan sumber daya merupakan bentuk 
keperdulian organisasi atau perusahaan yang mengacu pada kualitas kehidupan kerja tergolong baik. Ini menunjukkan bahwa kualitas kehiupan kerja memberikan keuntungan tersendiri bagi organisasi dan bagi karyawan.

Aspek-aspek kualitas kehidupan kerja meliputi lingkungan kerja, budaya dan iklim organisasi, hubungan dan kerjasama, pelatihan dan pengembangan, kompensasi dan hadiah, fasilitas, kepuasan kerja dan keamanan kerja, otonomi kerja, dan sumber daya yang cukup (Swamy dkk, 2015). Penelitian yang dilakukan oleh Nurdiyani (2012) menunjukkan bahwa kualitas kehidupan kerja memberikan pengaruh terhadap keterikatan kerja. Ketika kualitas kehidupan kerja tinggi maka keterikatan kerja juga akan tinggi hal ini berdasar hasil penelitian yang menunjukkan bahwa $R=$ 0,695 . Hasil penelitian serupa juga ditemukan oleh Kanten dan Sadullah (2012) mengenai hubungan antara kualitas kehidupan kerja dan keterikatan kerja yang menunjukkan bahwa terdapat hubungan positif antara kualitas kehidupan kerja dan keterikatan kerja.

Keterikatan kerja adalah sebuah perilaku positif yang mendorong karyawan dalam memenuhi tugasnya yang berhubungan dengan keadaan pikiran yang ditandai oleh tiga aspek yaitu semangat, dedikasi, dan keterserapan (Kanten \& Sadullah, 2012). Hal ini mengidentifikasikan bahwa keterikatan kerja mampu mendorong karyawan untuk bekerja secara optimal sehingga memperoleh hasil kerja yang lebih baik.

Uji independent sample $t$ test dilakukan bertujuan untuk melihat adanya perbedaan jawaban antara subjek yang belum menikah, sudah menikah tetapi belum memiliki anak dan subjek yang sudah menikah dan sudah memiliki anak terkait keterikatan kerja. Hasil uji perbedaan dengan menggunakan independent sample $t$ test, hasil diperoleh hasil sebagai berikut:

Tabel 2

Hasil Uji independent sample t test

\begin{tabular}{lll}
\hline \multicolumn{1}{c}{ Variabel } & \multicolumn{1}{c}{ Nilai Signifikansi } & \multicolumn{1}{c}{ Keterangan } \\
\hline $\begin{array}{l}\text { keterikatan kerja ditinjau dari } \\
\text { status pernikahan }\end{array}$ & 0,141 & tidak ada perbedaan \\
$\begin{array}{l}\text { keterikatan kerja dan jumlah } \\
\text { anak }\end{array}$ & 0,095 & tidak ada perbedaan \\
\hline
\end{tabular}

Dari hasil tersebut dapat disimpulkan bahwa, tidak ada perbedaan keterikatan kerja antara pekerja yang menikah dan belum menikah hal ini dapat dilihat dari $p=0,141 \quad(p>0,01)$ dan tidak ada perbedaan keterikatan kerja ditinjau dari jumlah anak $p=0,095(p>0,01)$.

\section{SIMPULAN}

Berdasarkan hasil analisis dapat disimpulkan bahwa terdapat hubungan positif yang sangat signifikan antara kualitas kehidupan kerja dengan keterikatan kerja pada pekerja wanita. Tidak ada perbedaan keterikatan kerja antara pekerja yang menikah dan belum menikah, dan tidak ada perbedaan keterikatan kerja ditinjau dari jumlah anak.
Berdasarkan hasil diatas, maka peneliti memberikan beberapa saran bagi perusahaan perlu mempertimbangkan pentingnya untuk memberikan kualitas kehidupan kerja serta hal-hal yang terkait lainnya dengan keterikatan kerja pada pekerja wanita agar, keterikatan kerja pada pekerja wanita dapat meningkat.

Bagi peneliti selanjutnya yang ingin melakukan penelitian mengenai keterikatan kerja dapat mempertimbangkan variabel lainnya dan lebih memperdalam hal-hal yang berkaitan dengan penelitian yang akan diteliti. Faktor-faktor lain yang mungkin memberikan pengaruh terhadap keterikatan kerja perlu dipertimbangkan.

Implikasi dalam penelitian ini dapat disimpulkan bahwa untuk meningkatkan 
kualitas karma maka diperlukan adanya rasa keterikatan dengan pekerjaan tersebut, kualitas yang baik akan membuat semakin produktif di lingkungan kerja.

\section{DAFTAR PUSTAKA}

Bakker, A. B. (2011). An evidence-based model of work engagement. Curr. Dir. Psychol. Sci. $20,265-69$

Bakker, A. B., \& Leiter, M. P. (Eds). (2010). Work Engagement: A Handbook of Essential Theory and Research. New York: Psychology Press.

Gayathiri, R., \& Ramakrishnan, L. (2013). Quality of work life - linkage with job satisfaction and performance. International Journal of Business and Management Invention, 2, 01-08

Grady, G. \& McCarthy, A. M. (2008). Work-life integration: experiences of mid-career professional working mothers. Journal of Managerial Psychology, 23(5), 599-622

Hakanen, J.J., Bakker, A.B., \& Schaufeli, W.B. (2006). Burnout and work engagement among teacher. Journal of school psychology. 43, 495-513

Jick, T. D., \& Mitz, L. F. (1985). Sex Differences in Work Stress. Academy of Management, $1(3), 408-420$

Ihromi, O. (1990). Wanita Bekerja dan Masalah-masalahnya, dalam Toety Hearty. Nurhadi., \& Hubeis, A. F. S. (editor), Jakarta : Dinamika Wanita Indonesia seri 01: Multidimensional, Pusat Pengembangan Sumberdaya Wanita

IImiah. (2015). Pengaruh kualitas kehidupan kerja dan modal psikologis terhadap keterikatan kerja karyawan PT Perkebunan III (Persero). Thesis. Medan: Universitas Sumatra Utara. http://id.123dok.com//document/ky61dgq0-pengaruh-kualitas-kehidupan-kerjadan-modal-psikologis-terhadap-keterikatan-kerja-karyawan-pt-perkebunan-nusantaraiii-persero-the-influence-of-quality-of-work-life-and-psychological-capital-toward-workegagement-of-pt-perkebunan-nusantara-iii-per.html

Islam, M. B. (2012). Factors Affecting Quality of Work Life: An Analysis on Employees of Private Limited Companies in Bangladesh. Global Journal of Management and Business Research, 12, 23-31

Kanten, S \& Sadullah, O. (2012). An empirical research on relationship quality of work life and work engagement. Procedia - Social and Behavioral Sciences, 62, 360 - 366

Lewis, D., Brazil, K., Krueger, P., Lohfeld, L., \& Tjam, E. (2001). Extrinsic and Intrinsic Determinants of Quality of Work Life. International Journal of health Care Quality Assurance Incorporating Leadership in Health Service, 14, 9-15

Nilakusmawati, D.P.E., Susilawati, M. (2012). Studi faktor-faktor yang mempengaruhi wanita bekerja di kota Denpasar. PIRAMIDA Jurnal Kependudukan dan Pengembangan Sumber Daya Manusia, 8(01), 26 - 31

Nohong, N. (2009). Peran ganda guru sebagai pekerja wanita dalam keluarga di kelurahan Tidung Makassar. Jurnal kajian perempuan "Bunga welulu", 14(01), 26-33

Normala \& Daud. (2010). Investigating the relationship between quality of work life and organizational commitment amongst employees in malaysian firms. International Journal of Business and Management, 5(10), 75-82 
Nurdiyani, I. (2012). Pengaruh kualitas kehidupan kerja dan kepemimpinan transformasional terhadap keterikatan kerja pada perawat. Skripsi (Tidak Diterbitkan). Yogyakarta: Universitas Gajah Mada. diunduh dari http://etd.repository.ugm.ac.id/index.php?mod=penelitian detail\&sub=PenelitianDetail \&act=view\&typ=html\&buku id=57140

Rahayuningsih, I. (2013). Kecenderungan intensi turnover tenaga kerja perempuan di perusahaan mie instant gresik. Digital library : universitas muhammadiyah Gresik,. Dilihat pada 01-Mei-2017 diambil dari http://digilib.umg.ac.id/gdl.php?mod=browse\&op=read\&id=jipptumg--idharahayu-1280

Schaufeli, W.B., Bakker, A.B. \& Rhenen, W.V. (2009). How changes in job demands and resources predict burnout, work engagement, and sickness absenteeism. Journal of Organizational Behavior, 30, 893-917

Schaufeli, W.B., Bakker, A.B. \& Salanova, M. (2006). The measurement of work engagement with a short questionnaire: A cross-national study. Educational and Psychological Measurement, 66, 701-716

Schaufeli, W.B., Salanova, M., Gonzalez Romá, V., \& Bakker, A.B. (2002). The measurement of engagement and burnout: a confirmative analytic approach. Journal of Happiness Studies, 3, 71-92.

Shidhaye, R.V., Divekar, D.S., Goel, G. \& Rahul, S. (2011). Influence Of Working Condition On Job Satisfaction In Indian Anesthesiologists:A Cross Sectional Survey. Indian Institute Of Public Health Journal, 15(1), 30-37

Shinha, C. (2012). Factors affecting quality of work life: empirical evidence from indian organizations. Australian Journal of Business and Management Research, 1(11), 3140

Stevenson, A. (2010). English Oxford Living Dictionary. Edisi ketiga: Oxford : Oxford University Press

Subashini, S. \& Gopal, C.S.R. (2013). Quality of work life among women employees working in garment factories in coimbatore district. Asia Pacific Journal of Research, 1, 22-29

Swamy, D.R., Nanjundeswaraswamy, T.S., \& Rashmi, S. (2015). Quality of work life: scale development and validation. International Journal of Caring Sciences, 8, 281-300

Yadaf, R., \& Khanna, A. (2014). Literature review on quality of work life and their dimensions. IOSR Journal Of Humanities And Social Science (IOSR-JHSS), 19, 71-80 